\title{
SHELLING, SNIPING AND STARVATION: THE LAW OF ARMED CONFLICT AND THE LESSONS OF THE SIEGE OF SARAJEVO
}

\author{
KJ Riordan*
}

This article looks at the siege of Sarajevo conducted from April 1992 to February 1996, which resulted in the loss of thousands of lives and great suffering to the civilian population of the city. It also resulted in criminal convictions for Bosnian Serb commanders Stanislav Galic and Dragomir Milosević. Given the fact that sieges have been a common form of warfare from antiquity to the present day, and are likely to remain so, these convictions and the heavy sentences that accompanied them must provide a cautionary tale for commanders who may in future be required to undertake such an operation. This article examines the traditional methods of warfare associated with the successful prosecution of a siege and contrasts them with the detailed and onerous provisions of the law of armed conflict. It ponders the question of what a modern commander must do to conduct a siege which is both lawful and successful.

\section{INTRODUCTION}

In November 1992, Major General Stanislav Galić was appointed as the commander of the Sarajevo Romanija Corps and immediately assumed de facto command of all Bosnian Serb Army (BSA) military personnel present at Sarajevo. ${ }^{1}$ This was an important step in his military career and

* Brigadier Kevin Riordan, ONZM is Director General of Defence Legal Services for the New Zealand Defence Force (NZDF). The views expressed in this article are personal and do not necessarily represent the position of the NZDF. The author is greatly indebted to the considerable help provided by Lieutenant Colonel Jim Cutler, RNZIR (retired) who served in Sarajevo from November 1992 to March 1993 with the United Nations Protection Force (UNPROFOR) as the Senior Military Observer (UNSMO) and as the Senior New Zealand National Officer. Lieutenant Colonel Cutler gave evidence at the trial of Major General Stanislav Galić. He has provided the author with much valuable detail relating to the conduct of the Siege of Sarajevo upon which this article is largely based. Any errors of fact are those of the author, not his.

1 The besieging forces of the Sarajevo Romanija Corps under Galić's command were a corps of the Bosnian Serb Army (BSA) - or in its Serbo-Croat anagram "VRS". Entire units of the Yugoslav National Army (JNA) had, when ordered to withdraw from Bosnia and Herzegovina (Bosnia-Herzegovina), simply 
one that was to have far-reaching effects on his life as well as the lives of thousands of inhabitants of the city. In that role, which he held for a period of nearly two years, General Galić was effectively responsible for the conduct of a significant part of the operation that came to be known as the "Siege of Sarajevo". 2

The siege of Sarajevo and its criminal consequences ${ }^{3}$ present a valuable case study in the modern law of armed conflict (LOAC) as it applies to fighting in towns and cities. As the world's population continues to grow, it seems less and less likely that warfare can be confined to sparsely populated places. Almost all military engagements of the 21 st century have seen fighting in urban environments. This article asks what we can learn from the Sarajevo experience and whether the developments in the LOAC have now made it very difficult for a commander to conduct a siege that is both successful and lawful. ${ }^{4}$

\section{MODERN PRECONDITIONS FOR A MEDIEVAL SIEGE}

This article will not set out a detailed history of the battle and siege of Sarajevo, ${ }^{5}$ a military engagement which lasted from April 1992 until February 1996 and resulted in the loss of as many as 19,000 combatant and civilian lives. ${ }^{6}$ However, in order to understand how the complex strands of

transformed themselves into BSA units. Most of the BSA soldiers and officers had, therefore, come from a generally well-trained professional army which, before the war, had run an advanced law of armed conflict (LOAC) training programme. The Corps was believed to number some 18,000 soldiers.

2 Major General Galić was replaced as commander by Major General Dragomir Milosević on 10 August 1994. The pattern of warfare started by Galić was continued by Milosević, who was himself sentenced to 33 years' imprisonment by the International Tribunal for the former Yugoslavia (ICTY) for his part in the siege. On 10 November 2009, this sentence was reduced on appeal to 29 years' imprisonment: see Prosecutor v Dragomir Milosević (Judgment) (12 November 2009) IT-98-29/1-A (Appeals Chamber, ICTY).

3 This article does not examine in depth the various important procedural and evidentiary features of Galić's trial, or equally interesting questions such as the basis for Galić's command responsibility. Nor will the findings of fact be critiqued. This article concentrates only on the lessons for future conduct of siege warfare that are to be learned from its judgment.

4 See generally T Gjelten "Siege" in Roy Gutman, David Rieff and Kenneth Anderson (eds) Crimes of War: What the Public Should Know (WW Norton \& Company, New York, 1999) 336.

5 Very full details of the background to the operation are set out in Prosecutor v Stanislav Galić (Judgment) (5 December 2003) IT-98-29 (Trial Chamber, ICTY) at [192]-[205] [Galić Trial]. The details of the siege are revisited and the factual findings largely confirmed in Prosecutor v Stanislav Galić (Judgment) (30 November 2006) IT-98-29 (Appeals Chamber, ICTY) [Galić Appeal] and again in Prosecutor v Dragomir Milosević (Judgment) (12 December 2007) IT-98-29/1-T (Trial Chamber, ICTY) [Milosević Trial].

6 Estimates of casualties, as always in war, are prone to be exaggerated or minimised by one side or the other. The oft-quoted figure of 10,000 civilians killed or missing and 56,000 wounded is derived from a United Nations Security Council report which in fact only covered the period up to 15 November 1993. It is based on figures from the Bosnia Herzegovina Institute of Public Health and the reports of UNPROFOR. See United Nations Commission of Experts Final Report of the United Nations Commission of Experts established pursuant to Security Council Resolution 780 (1992) SC Res 674, S/Res/1994/674 (1994) [Final 
both international humanitarian law and international criminal law applied to the engagement, it is necessary to consider how it was that the parties to the conflict came to be in the position that they were when Galić assumed command.

On the break-up of Yugoslavia in 1990-1991, the central Yugoslav Republic known as Bosnia and Herzegovina (Bosnia-Herzegovina) declared itself to be an independent sovereign State. ${ }^{7}$ Within its borders, however, there were two self-identifying ethnic groups with powerful neighbouring connections; namely, the Bosnian Croats and Bosnian Serbs. ${ }^{8}$ In Sarajevo, which had often been held up as a model of multi-ethnic tolerance, ${ }^{9}$ these two groups constituted respectively about seven per cent and 30 per cent of the population, with Bosnian Moslems making up about 50 per cent of the population. ${ }^{10}$ Many Bosnian Serbs viewed the creation of an independent BosniaHerzegovina as essentially isolating a significant number of Serbs of the Orthodox Christian faith within a Moslem-dominated State. This State, they were assured by their propagandists, would soon become a fundamentalist polity in which Christians would, if not slaughtered outright, at least become second-class citizens. ${ }^{11}$ Nationalism, political opportunism, racism, fear of encirclement, dormant historical hatred and religious intolerance were manipulated by all parties (to a greater or lesser extent) to the point that a significant number of Serbs in Sarajevo saw their survival as a national group being guaranteed only by incorporation within a notionally independent Bosnian

Report of the United Nations Commission of Experts]. Military casualties appear to be about 6,300 killed on the defending side, and 2,600 on the part of the besiegers. The majority in the Trial Chamber used a conservative estimate which put the minimum number of persons killed within the confrontation line in Sarajevo during the indictment period at 3,798, of whom 1,399 were civilians. The minimum number wounded in the same period was 12,919, including 5,093 civilians: see Galić Trial, above n 5, at [579]. The separate and dissenting judgment of Judge Rafael Nieto-Navia of Colombia uses these same figures (which actually only applied to six municipalities within Sarajevo) to hypothesise that the death rate was too low to justify allegations of a deliberate campaign against civilians: see Prosecutor v Stanislav Galić (Separate and Partially Dissenting Opinion) (5 December 2003) IT-98-29-T (Trial Chamber, ICTY) at [105] Judge NietoNavia [Separate and Partially Dissenting Opinion of Judge Nieto-Navia].

7 Bosnia-Herzegovina made a declaration of sovereignty in October 1991 which was followed by a declaration of independence from the former Yugoslavia on 3 March 1992 after a referendum that was largely boycotted by ethnic Serbs.

8 The division between Croats, Bosniaks (Bosnian Moslems) and Serbs is confessional or religious, rather than racial. All three groups are Southern Slavic. Although there are many political motives behind the war, the Balkan War is almost invariably referred to as an ethnic conflict. See generally Valère Philip Gagnon Jr "Historical Roots of the Yugoslav Conflict" in Milton Esman and Shibley Telhami (eds) International Organisations and Ethnic Conflict (Cornell University Press, Ithaca, 1995) 179.

9 See Milosević Trial, above n 5, at [11].

10 Smaller ethnic minorities and persons who regarded themselves simply as Yugoslavs made up the rest of the population. See Prosecutor v Stanislav Galić (Indictment) (26 March 1999) IT-98-29 (ICTY) at [1].

11 For a discussion of this manipulation of fears, see Misha Glenny The Fall of Yugoslavia: The Third Balkan War (Penguin Books, New York, 1992). 
Serb State which they called "Republika Srpska". ${ }^{12}$ Although for the time being this entity would remain within the borders of Bosnia-Herzegovina, few doubted that amalgamation within a greater Serbia was the ultimate aim. Many Bosnian Moslems equally concluded that their physical safety, as well as their survival as a viable State, was threatened by the rise of Serb nationalism within their borders.

Sarajevo, a densely populated city of 340,000 to 500,000 inhabitants and already the capital of the Yugoslav Republic of Bosnia-Herzegovina, was naturally selected by the Bosnia-Herzegovina government to be the capital of the new State. It was the most important city in the region from the political, commercial, industrial and cultural point of view. As such, it was regarded as vital to all ethnic groups in Bosnia-Herzegovina, both symbolically, and because of its strategic location. ${ }^{13}$ Surrounded as it was by steep hills, the growing violence throughout the basin in which Sarajevo sat quickly forced all groups to choose between getting out of the city, and not being able to get back in; or staying in the city, and not being able to get out. Within weeks, Bosnia-Herzegovina's Presidency Forces (Presidency Forces) held the city and the Bosnian Serbs had secured most of the surrounding hills. It was clear from an early stage, therefore, that possession or control of Sarajevo would be militarily contested. Just how violently it would be contested, however, surprised almost everyone.

\section{THE LEGAL LANDSCAPE}

In the modern war period, a force which occupies a town or city and which faces imminent battle with the enemy has (in theory at least) two options. First, there is the option of declaring the place to be what has historically been known as an "open city", ${ }^{14}$ now technically known in the LOAC as a "non-defended locality". ${ }^{15}$ The force thereby secures legal protection for the place and

12 The Serbian Republic of Bosnia Herzegovina (Republika Srpska) was proclaimed by a Serb nationalist assembly on 9 January 1992 with the declared aim of seceding from Bosnia-Herzegovina and joining the Socialist Former Republic of Yugoslavia. See Galić Trial, above n 5, at [195].

13 Ibid, at [197].

14 During World War II, Brussels (1940), Paris (1940), Belgrade (1941), Manila (1942), Athens (1944) and Rome (1943 and 1944) were all declared open cities. Although the attack by German bombers on the city of Rotterdam was condemned as a war crime by the Prosecution at Nuremberg, it was not in fact an open city since Dutch Marines were continuing their defence at the time of the attack. See United States of America $\mathrm{v}$ Herman Goering (Trial of the Major War Criminals) (1946) 9 Nuremberg Trial Proceedings 338. The air attack by the Allies on the city of Dresden in February 1945, allegedly an open city by consensus (though not having been declared as one), has since been widely condemned, but produced no jurisprudence since no one was charged with any offence as a result.

15 Protocol Additional to the Geneva Conventions of 12 August 1949, and relating to the Protection of Victims of International Armed Conflicts (Protocol I) (opened for signature 8 June 1977, entered into force 7 December 1978) [Geneva Protocol I], art 59(2) provides that the appropriate authorities of a party to the conflict may declare as a non-defended locality any inhabited place near or in a zone where armed forces are 
its civilian inhabitants from the damage and casualties of assault, ${ }^{16}$ but at the cost of removing all forces and weapons from, and abandoning any strategic value of, the place to the enemy. ${ }^{17}$ This option evidently fits better with the general precautionary obligations of the LOAC to take constant care to spare the civilian population, civilians and civilian objects. ${ }^{18}$ Equally clearly, such a decision is usually based on a high level of confidence that the protections of the law will, in fact, be applied by the opposing force.

Secondly, military forces in control of an urban area can contest the issue by force in the streets, or indeed, house-to-house. The decision to make a fight of it in the city or town is not prohibited by the LOAC although a defending force is exhorted to take precautions "to the maximum extent feasible" to avoid placing military objectives close to civilian and protected objects. ${ }^{19}$ In a densely

in contact which is open for occupation by an adverse party. The expression is largely synonymous with an "undefended locality". See also art 60 for demilitarised zones.

16 Convention (IV) Respecting the Laws and Customs of War on Land and Its Annex: The Regulations Concerning the Laws and Customs of War on Land (opened for signature 18 October 1907, entered into force 26 January 1910) [Hague Regulations 1907], annex at art 25 provides that it is prohibited to attack or bombard, by whatever means, towns, villages, dwellings or buildings which are undefended. Hague Convention (IX) concerning Bombardment by Naval Forces in Time of War (opened for signature 18 October 1907, entered into force 26 January 1910) [Hague Convention IX], art 1 provides that the bombardment by naval forces of undefended ports, towns, villages, dwellings or buildings is forbidden. Note that the provisions of Hague Convention IX, art 3 relating to attacks on places declining to comply with requisitions no longer reflect the LOAC. Hague Rules concerning the Control of Wireless Telegraphy in Time of War and Air Warfare (drafted by a Commission of Jurists at the Hague, 11 December 1922-17 February 1923, but never adopted) reproduced in D Schindler and J Toman (eds) The Laws of Armed Conflicts (4th ed, Martinus Nijhoff Publisher, Leiden, 2004) 315 [Draft Rules of Aerial Warfare], art 24(3) provides that the bombardment of cities, towns, villages and dwellings not in the immediate neighbourhood of the operation of land forces is prohibited. Geneva Protocol I, above n 15, art 59(1) provides that it is prohibited to attack non-defended localities by any means whatsoever. Art 85(3)(d) provides that making non-defended localities and demilitarised zones the object of attack is a grave breach. Rome Statute of the International Criminal Court (opened for signature 17 July 1998, entered into force 1 July 2002) [Rome Statute], art $8(2)(\mathrm{b})(\mathrm{v})$ provides that attacking or bombarding by whatever means towns, villages, dwellings or buildings which are undefended and which are not military objectives is a war crime. There is no equivalent provision in respect of armed conflict not of an international character. However, by definition, non-defended localities are not military objectives and, therefore, subjecting them to attack without military necessity would still be punishable under art $8(2)(\mathrm{e})(\mathrm{i})$ and (xi) of the Rome Statute.

17 Acts of hostility against the occupiers by the authorities or the civilian population are also prohibited, as are actions in support of military operations. See Geneva Protocol I, above n 15, art 59(2)(a)-(d).

18 Ibid, art 57(1)

19 Ibid, art 58(a) provides that parties to the conflict must, to the maximum extent feasible, endeavour to remove the civilian population, individual civilians and civilian objects under their control from the vicinity of military objectives; art 58(b) provides that parties to the conflict must, to the maximum extent feasible, avoid locating military objectives within or near densely populated areas. For commentary on applicable customary international law, see Jean-Marie Henckaerts and Louise Doswald-Beck Customary International Humanitarian Law (Cambridge University Press and International Committee of the Red Cross (ICRC), 
populated city such as Sarajevo, the feasibility of such a precaution may prove to be quite limited in reality. When the environment comprises entirely civilian objects, the best that may be achieved is to avoid locating military objectives close to especially protected objects such as hospitals. The defenders are also prohibited from deliberately using the civilian population as a "human shield" so as to protect military objectives or operations from attack..$^{20}$

The options for the Presidency Forces ${ }^{21}$ were, however, narrowed by two important facts. First, as noted above, Sarajevo was their capital, the loss of which would have gravely affected their capacity to demonstrate sovereignty within the territory of their newly proclaimed State. Secondly, the BSA's concept of operations was inextricably linked with the doctrine of "ethnic cleansing" by which non-Serb civilians would have almost certainly been expelled from the city, probably in circumstance of great brutality. ${ }^{22}$ The fall of Srebrenica was later to illustrate that this fear was far from unfounded. ${ }^{23}$ To declare Sarajevo to be "non-defended" would, therefore, have been to

Cambridge, 2005) vol 1 rule 23 [ICRC Customary International Humanitarian Law Study]. In fact, the defenders will often find it in their interest to prevent the civilian population from leaving and there is some evidence that this occurred in Sarajevo: see Separate and Dissenting Opinion of Judge Nieto-Navia, above n 6 , at [8].

20 Convention (IV) relative to the Protection of Civilian Persons in Time of War (opened for signature 12 August 1949, entered into force 21 October 1950) [Geneva Convention IV], art 28 provides that the presence of a protected person may not be used to render certain points or areas immune from military operations. Geneva Protocol I, above n 15, art 51(7) provides that the presence or movements of the civilian population or individual civilians shall not be used to render certain points or areas immune from military operations, in particular in attempts to shield military objectives from attacks or to shield, favour or impede military operations. It is prohibited to direct the movement of the civilian population or of individual civilians in order to attempt to shield military objectives from attacks or to shield military operations. Rome Statute, above $\mathrm{n} \mathrm{16}$, art $8(2)(\mathrm{b})$ (xxiii) provides that utilizing the presence of civilians to render certain points, areas or military forces immune from military operations is a war crime. See Prosecutor $v$ Tihomir Blaškić (Judgment) (29 July 2004) IT-95-14-A (Appeals Chamber, ICTY) at [235]-[236] [Blaškić Appeal]. For commentary on applicable customary international law relating to "human shields", see ICRC Customary International Humanitarian Law Study, above n 19, rule 97.

21 The defence of the city was primarily conducted by the First Corps Sarajevo of the Bosnia and Herzegovina Forces, a body of between 30,000 and 70,000 fighters of mixed quality and training. These forces are frequently referred to as "Bosniak" forces or "Bosnian Moslem" forces, suggesting that they contained only Moslems, which was not the case. They are often also referred to as "Presidency Forces" because they remained loyal to President Izetbegovic, and it is by this term that they are described in this article. Within the city there were also some Bosnian Croat units in a general but shaky alliance with the Presidency Forces, and some very troublesome paramilitary and criminal forces not controlled by either side. See Separate and Partially Dissenting Opinion of Judge Nieto-Navia, above n 6, at [4].

22 It was probably with this very potential in mind that the drafters of Geneva Protocol I, above n 15, art 58 made the obligation to remove civilians from the vicinity of military objectives expressly without prejudice to Geneva Convention IV, above n 20, art 49, which amongst other things prohibits massed forcible transfers and deportations of civilians.

23 For full details of what is now commonly referred to as the Srebrenica genocide, see Prosecutor $v$ Radislav Krstić (Judgment) (2 August 2001) IT-98-33-T (Trial Chamber, ICTY) and Case Concerning the 
abandon civilians of Moslems identity (and probably Bosnian Croats and other minorities too) to a most uncertain fate. Such a decision was, in any event, not available from a strategic point of view since it is hard to imagine where Presidency Forces would have moved to, had they abandoned the town.

\section{THE SOLDIER'S WORST NIGHTMARE}

On the other side of the ledger, there is no question but that General Galic was, under the LOAC ${ }^{24}$ legally entitled to attack the combatant members of the Presidency Forces located in the city. Those parts of the city used by Presidency Forces in support of their combat action were military objectives ${ }^{25}$ and, therefore, subject to the restrictions imposed by the normal LOAC (discussed further below), open to attack. Similarly, civilians who took a direct part in hostilities lost their immunity from attack while doing so. ${ }^{26}$ Presidency Forces did not become immune from attack simply by virtue of being in a defensive position within a city.

Furthermore, it must be recognised that Galić's tactical situation was not without its difficulties. Fighting in a built up area (widely referred to by its military acronym as "FIBUA") is well-known to

Application of the Convention on the Prevention and Punishment of the Crime of Genocide (Bosnia and Herzegovina $v$ Serbia and Montenegro) (Judgment) [2007] ICJ Rep 1.

24 This article does not address the jus ad bellum question of whether the use of force by the BSA against the Presidency Forces was per se lawful or unlawful. It is directed solely to the jus in bello issue of how that warfare was conducted.

25 Geneva Protocol I, above n 15, art 52 provides that, in so far as objects are concerned, military objectives are limited to those objects which by their nature, location, purpose or use make an effective contribution to military action and whose partial or total destruction, capture or neutralization, in the circumstances ruling at the time, offers a definite military advantage. See also ICRC Customary International Humanitarian Law Study, above n 19 , rule 8 .

26 Despite attempts to clarify the rules in this regard, the question what, exactly, constitutes "taking a direct part in hostilities" continues to be one of considerable debate. See Nils Melzer Interpretive Guidance on the Notion of Direct Participation in Hostilities (ICRC, Geneva, 2009). The issue did not present particular difficulties for the majority in the Trial Chamber in the Sarajevo context, however, since the incidents selected by the Prosecution generally related to casualties of an unequivocally civilian nature. The definition nevertheless presents dilemmas in siege warfare as in open warfare. Since few of the Presidency Forces were actually trained soldiers, they were highly reliant on various militias that sprang up in response to the threat. Some use was also made of certain well-known criminal elements. In other contexts, it had been argued that since almost all adult males played some part in the fighting, they remained a lawful target wherever they might be, including at home at the end of their fighting "shift". See Blaškić Appeal, above n 20, at [114]: "[i]f he is indeed a member of an armed organization, the fact that he is not armed or in combat at the time of the commission of the crimes, does not accord him civilian status". Better use might have been made of this argument by Galić had there been any evidence of distinction or proportionality in targeting such people. The question of combatants mingling with civilians was one that Galic raised in the context of both the crime and sentencing: see Galić Appeal, above n 5, at [420]. The presence within the civilian population of individuals who do not come within the definition of civilians does not, however, deprive the population of its civilian character: see Geneva Protocol I, above n 15, art 50(3). 
armed forces throughout the world as being a particularly challenging environment and one that many commanders will avoid, if given the choice. ${ }^{27}$ That a militarily inferior force in a fortified position can hold at bay a militarily superior armed force almost indefinitely is a constant lesson of history. Furthermore, the presence of civilians makes the attacker's job vastly more complex. As Colonel David Fraser remarked: "[h]ow do you get inside to a target that is surrounded by noncombatants? It is a soldier's worst nightmare". ${ }^{28}$ As will become apparent, the LOAC challenges associated with FIBUA are significant too, although the evidence would suggest that fact did not play heavily on the minds of the BSA command.

Unless an enemy force located in a city is driven out in the first assault, or withdraws of its own free will, the result is a siege. This term means nothing more or less than the encirclement of a populated area with the intent to cut off members of the opposing force from supplies and reinforcement - and to stop them from escaping from that area. It may last a matter of days, or it may, as in the case of Sarajevo, last for years.

\section{THE LAW OF SIEGE}

Siege warfare is not per se an unlawful method of combat. It is not proscribed in any convention, nor is it prohibited by customary international law. ${ }^{29}$ The Hague Regulations of 1907 provided explicit rules for the conduct of siege (discussed further below), while Geneva Protocol I, in updating that law, makes no mention of the term "siege" at all. The Red Cross Commentaries to Protocol I observe that the use of siege as a method of warfare remains legitimate, provided it is directed "exclusively against combatants". ${ }^{30}$ The concept of siege is mentioned but twice in the Geneva Conventions of $1949 .{ }^{31}$ The Trial Chamber of the International Criminal Tribunal for the

27 As Commander William Fenrick, Rapporteur of the United Nations Commission of Experts on legal issues and also for on-site investigations of the Canadian War Crimes Investigation Team who assisted the United Nations Commission of Experts, notes, the BSA was "not keen to participate in FIBUA" for a number of reasons, including the potential for disproportionate casualties, particularly in infantry personnel (which were in short supply) and tanks: see Canadian War Crimes Investigation Team "On-Site Report" (August 1993) at 24 [Fenrick Report].

28 Partially dissenting judge Nieto-Navia was so impressed with this statement by the United Nations representative posted to Sarajevo in 1994 that he quotes it three times in his opinion: see Separate and Partially Dissenting Opinion of Judge Nieto Navia, above n 6, preambular quotation and at [9] and [122].

29 For commentary on applicable customary international law, see Jean-Marie Henckaerts and Louise Doswald-Beck Customary International Humanitarian Law (Cambridge University Press and ICRC, Cambridge, 2005) vol 2 at 1138-1143. The study refers to a number of military manuals, including that of New Zealand, all of which conclude that siege is a lawful method of warfare.

30 ICRC Commentary on Additional Protocols of 8 June 1977 to the Geneva Conventions of 12 August 1949 (ICRC, Geneva, 1987) at 1457.

31 The duty to make local arrangements for the removal or exchange of wounded and sick from a besieged or encircled area, and for the passage of medical and religious personnel and equipment on their way to that area, is set out in the Convention for the Amelioration of the Condition of the Wounded and Sick in Armed 
Former Yugoslavia (ICTY) in the Galić trial only ever uses the word "siege" when quoting from evidence, and the closest it comes to using the word itself is when it refers to the conditions in Sarajevo as "siege-like". ${ }^{32}$ Furthermore, it found that "[i]n itself, that encirclement [of Sarajevo] is not directly relevant to the charges of the Indictment", ${ }^{33}$ suggesting that the Trial Chamber did not consider that such warfare changed the LOAC in any material way.

The State custom of conducting warfare by siege is by no means rare and a study of history from the fall of Jericho ${ }^{34}$ through to the current day would be hard pressed to decide whether sieges or open battles were historically the more common, or more decisive, form of battle. Given the preference of Māori forces to engage their enemy from the tactical advantage of a well placed pā, it is not surprising that throughout most of the pre-European and as well as the European war period in New Zealand the siege was not the exception, but the rule. Sieges played an important part in New Zealand's military history with many of the best-known engagements, such as Gate Pā, ${ }^{35}$ Rangiriri, ${ }^{36}$ Ngatapa $^{37}$ and Orakau, ${ }^{38}$ all fitting within this category.

A classic example of the conduct of siege warfare in compliance with the LOAC in the modern war period was the attack by the New Zealand 3rd (Rifles) Brigade on the German forces occupying the town of Le Quesnoy on 4 November 1918. The New Zealand forces, aware of the potential for excessive loss of civilian life and incidental damage to the medieval town, used the element of surprise to scale the ancient wall of the town with ladders and engage the Germans at close range with infantry small arms. The action was a spectacular success which also minimised civilian losses

Forces in the Field (opened for signature 12 August 1949, entered into force 21 October 1950) [Geneva Convention I] art 15. Similarly, Geneva Convention IV, above n 20, art 17 requires that parties to the conflict must endeavour to conclude local agreements for the removal from besieged or encircled areas, of wounded, sick, infirm and aged persons, children and maternity cases, and for the passage of ministers of all religions, medical personnel and medical equipment on their way to such areas.

32 Galic Trial, above n 5, at [765]. Other than repeating this passage, the Appeals Chamber does not use the expression at all.

33 Ibid, at [609].

34 The Bible Joshua 6:1-27. Whether the city fell in the way described or at that time is open to debate.

35 See Gilbert Mair The Story of Gate Pa April 29th, 1864 (Bay of Plenty Times, Tauranga, 1937) at 9.

36 James Cowan The New Zealand Wars: A History of the Maori Campaigns and the Pioneering Period: Volume I: 1845-1864 (RE Owen, Wellington, 1955) at $326<\mathrm{http} / / /$ www.nzetc.org>.

37 For an account of this short but bloody siege and comment on the law of war aspects, see Waitangi Tribunal Turanga Tangata Turanga Whenua: The Report on the Turanganui a Kiwa Claims: Wai 814 (Legislation Direct, Wellington, 2004) at 223-251.

38 Cowan, above $\mathrm{n} 36$, at 365 . 
and incidental damage to civilian property and cultural property. But this was a very lucky turn of events, and it would be naive to think that many sieges can be conducted with such decency. ${ }^{39}$

\section{THE TACTICS OF SIEGE}

As a professional soldier with some knowledge of military history, Galić would also have known that throughout time there have been five tried and true methods, used alone or in combination, for effectively laying siege to a fortified position. Successful prosecution of such warfare relies on any or all of the tactics of assault, bombardment, starvation, trickery ${ }^{40}$ and terror. ${ }^{41}$

Whether or not Galić attempted to use trickery such as ruses of war (which are lawful) or treachery (which is not) in the siege of Sarajevo is not well documented. Certainly, he was not indicted for any crime indicating treachery. ${ }^{42}$ Similarly, the various assaults made against the fortified positions of the town were tentative and short-lived. ${ }^{43}$ What is quite apparent is that he made ample use of a combination of the other three methods - bombardment, starvation and terror, with what transpired to be tragic human cost and serious consequences in terms of his individual criminal responsibility.

\section{THE CRIMINAL CONSEQUENCES}

On 5 December 2003, nine years after he relinquished command of the Sarajevo operation, the ICTY Trial Chamber found Galic guilty of five offences, namely: acts of violence, the primary

39 Sir Charles Lucas The Empire at War (Oxford University Press, London, 1924) vol 3 at 367.

40 The most famous example of a fortress being invested through a trick must be the legend of the siege of Troy by the Greeks as referred to in Homer's Iliad and its fall as described by Euripides in the Trojan Women. A lesser-known, but by no means less daring, example from New Zealand's history was the taking of the pā at Ahipara called Whangatauatea by a toa of Ngati Kuri reputed to have disguised themselves as the carcass of a beached whale using dog-skins: "... the inhabitants rushed from their fortifications to seize this apparent gift from the sea. The deceived Te Aupouri were ambushed. Trapped outside their protective works, without weapons, they suffered a terrible slaughter". It is from this event that Ngati Kuri derived their tribal name. See Waitangi Tribunal Report of the Waitangi Tribunal on the Muriwhenua Fishing Claim: Wai 22 (Waitangi Tribunal, Wellington, 1988) appendix 2 (Identities and Inter-Relationships of the Claimant Tribes).

41 Over the centuries, a significant number of fortresses have been surrendered for fear of the consequences of putting up a fight. This is described in further depth below.

42 See Prosecutor v Stanislav Galić and Dragomir Milosević (Initial Indictment) (24 April 1998) IT-98-29-I (ICTY); Galić Indictment, above n 10.

43 Whether Galić ever considered that he would be able to take the town by assault, or even desired to do so, is doubtful. Although vastly better armed in tanks, artillery and mortars, the BSA forces were numerically inferior to the Presidency Forces inside the city, who outnumbered them by possibly as much as five to one. It is probable that Galić's immediate aim was simply to contain the Presidency Forces until he was sufficiently reinforced to take the town by storm, or until political concessions could be obtained, and to kill as many Bosnian Moslems as was possible during the interval. 
purpose of which was to spread terror among the civilian population, a violation of the laws or customs of war, ${ }^{44}$ as set forth in Article 51 of Geneva Protocol I (count 1) ${ }^{45}$ murder as a crime against humanity through sniping (count 2); inhumane acts other than murder as crimes against humanity through sniping (count 3); murder as a crime against humanity through shelling (count 5); and, inhumane acts other than murder as crimes against humanity through shelling (count 6). Galić was sentenced to a single sentence of 20 years' imprisonment. Both the Prosecution and Galic appealed the sentence, and Galić appealed the decision. In late 2006, the Appeals Chamber of the ICTY dismissed the appeal, and increased the sentence to life imprisonment. ${ }^{46}$

At the outset of the trial, the Prosecutor had alleged that "not since World War II had a professional army conducted a campaign of such unrelenting violence against the inhabitants of a European city" - a clear reference to cases such as the siege of Leningrad. ${ }^{47}$ Yet, Field Marshal Wilhelm von Leeb, the German commander at that siege, had been acquitted for his actions in respect of his equally unrelenting violence against the inhabitants of that city, including shelling civilians as they tried to flee out of the city. ${ }^{48}$ What then had changed since von Leeb was tried in 1947? And, notwithstanding the fact that sieges themselves remain per se lawful, had those changes in the law effectively made it virtually impossible for a commander to conduct a successful siege that also complies with the LOAC ${ }^{49}$

\section{SHELLING}

Attack upon a fortified place by bombardment or shelling (whether by air attack, artillery or naval gunfire) is for the attacker the strategy over which he or she exercises the greatest element of control. Once a modern artillery piece, such as those that surrounded the basin in which Sarajevo is located, is registered on target, ${ }^{50}$ the commander can be almost certain of hitting any target he or she

44 Galić Trial, above n 5, at [309].

45 As a consequence of the finding of guilt it entered on count 1, the Trial Chamber dismissed counts 4 and 7 (attacks on civilians as set forth in Geneva Protocol I, above n 15, art 51 and Protocol Additional to the Geneva Conventions of 12 August 1949, and relating to the Protection of Victims of Non-International Armed Conflicts (Protocol II) (opened for signature 8 June 1977, entered into force 7 December 1978) [Geneva Protocol II], art 13 as a violation of the laws or customs of war).

46 Galić Appeal, above n 5, at [185].

47 The siege of Leningrad (St Petersburg) lasted 872 days and cost the lives of between 600,000 and one million civilians.

48 US v von Leeb (High Command Case) (1948) 12 LRTWC 1 [High Command Case].

49 See Gjelten, above n 4.

50 The use and control of artillery assumed some importance in the Galić case. A gun is registered by mathematical calculation of its bearing and elevation. Once the fall of shot has been observed and registered, the commander has a high level of confidence that any round fired on the same charge, bearing and elevation will land on the same target. This is particularly so when the guns remain in almost the same 
chooses, whether a lawful military objective or not. ${ }^{51}$ Galić had at his disposal 1,100 artillery pieces and mortars and a significant number of tanks which were effectively used as mobile artillery pieces. He also, seemingly, had no shortage of ammunition - a rare bonus for any commander. This is a disproportionately heavy amount of fire power for a formation of that size and it largely dictated the course of the battle.

The Presidency Forces, on the other hand, had fewer weapons of this nature. They were mostly reliant on small arms, rockets and mortars, the latter often fired from the backs of trucks. Although they significantly outnumbered the Bosnian Serbs in infantry, they could do little by way of counterbattery fire to disrupt the BSA shelling onslaught. ${ }^{52}$

United Nations Protection Force (UNPROFOR) ${ }^{53}$ observers reported that on "quiet" days from 200 to 300 impacts would land upon the city. On an "active day", as many as 1,000 shells would impact whereas a heavy day would push the number as high as $3,777 .{ }^{54}$ Observers recorded that 64,490 shells hit the city in the first six months of the siege. The United Nations Expert Commission, however, considered that Sarajevo had been hit by a far greater number of shells than was recorded. ${ }^{55}$ The use of this firepower to terrorise the population is dealt with further below; however, the shelling of the city engaged other LOAC principles as well.

place for two years. The use of artillery is also tightly controlled by a commander: see Galić Trial, above n 5, at [696]-[699]. The Trial Chamber's conclusion was that Galić had ordered his gunners to fire indiscriminately.

51 Inaccurate shelling with modern artillery is only likely to occur through ammunition failure or gunner error. See Lieutenant Colonel Cutler's evidence relating to accusations of drunken artillerymen in Galić Trial, above n 5, at [641]. Overall, however, the Bosnian Serb gunners were judged by United Nations observers to be "professional and efficient" (at [617]) leading to the conclusion that civilian casualties were not accidental. See also evidence of the indiscriminate effect of using of heavy artillery to attack so-called military targets consisting of one building or one vehicle (at [648]), and the use of inherently indiscriminate weapons such as the multi-barrelled rocket launcher (at [644]).

52 This is not to suggest, however, that the battle was entirely one-sided. See for example the evidence referred to in Separate and Partially Dissenting Opinion of Judge Nieto-Navia, above n 6, at [15]-[16], including the evidence of another New Zealand officer, Lieutenant Colonel Richard Gray.

53 UNPROFOR, established by SC Res 734/1992, S/RES/734/1992 (1992), and to which New Zealand contributed forces from March 1992 to January 1996. Although originally established to protect the provision of humanitarian aid in the Former Yugoslavia, the roles and tasks of the mission rapidly expanded during the course of its mandate.

54 Final Report of the United Nations Commission of Experts, above n 6, annex VI at 1 (Study of the battle and siege of Sarajevo) and annex IV at 10.

55 Ibid, annex IV at 9. 
The LOAC requires that the only legitimate purpose for which armed force can be used is to weaken the enemy forces and bring about their submission. ${ }^{56}$ The rules of LOAC relating to the means and methods of combat are intended to ensure that the destructive effects of combat action are limited as much as possible to enemy combatants and property of military significance. ${ }^{57}$ There are three overlapping, but discrete elements of this obligation, known simply as "distinction", namely:

(a) the absolute prohibition on deliberately targeting individual civilians and the civilian population, ${ }^{58}$ civilian objects ${ }^{59}$ and other specifically protected persons and objects ${ }^{60}$ for so long as those persons do not take a direct part in the hostilities and the objects do not become military objectives, ${ }^{61}$

56 Declaration Renouncing the Use, in Time of War, of Explosive Projectiles Under 400 Grammes Weight (adopted 11 December 1868, entered into force 11 December 1868). The basic principle set out in this Treaty is now regarded as a foundation of customary international law.

57 See generally William J Fenrick "Attacking The Enemy Civilian As A Punishable Offense" (1997) 7 Duke J of Comp and Int'l L 539 .

58 Hague Regulations 1907, above n 16, art 46 provides that the lives of (civilian) persons must be respected. Geneva Protocol I, above n 15, art 51(2) provides that it is prohibited to make the civilian population as such, as well as individual civilians, the object of attack; art 85(3)(a) provides that making the civilian population or individual civilians the object of attack is a grave breach. Note also Geneva Protocol II, above n 45, arts 4(2)(a) and 13(2), which protect civilians in armed conflict not of an international character. Rome Statute, above $\mathrm{n} 16$, art $8(2)$ (b)(i) now provides that intentionally directing attacks against the civilian population as such, or against individual civilians not taking direct part in hostilities, is a war crime within the jurisdiction of the International Criminal Court; art 8(2)(e)(i) in respect of armed conflict not of an international character. See also ICRC Customary International Humanitarian Law Study, above n 19, rule 6 , which states that civilians are protected against attack, unless and for such time as they take a direct part in hostilities.

59 Geneva Protocol I, above n 15, art 52(1) provides that civilian objects shall not be the subject of attack. See also ICRC Customary International Humanitarian Law Study, above n 19, rule 7, which states that the parties to the conflict must at all times distinguish between civilian objects and military objectives. Attacks may only be directed against military objectives. Attacks must not be directed against civilian objects.

60 Specifically protected persons and objects include any person or object enjoying a protection under the LOAC over and above any protection applicable to that person or object by virtue of being civilian. This includes: persons who are hors de combat through wounds, sickness, shipwreck or any form of detention, medical units, transport and personnel, cultural and religious property, installations containing dangerous forces and the personnel and property of United Nations and civil defence organisations, neutral persons, safety zones and other places or persons protected by agreement or by truce.

61 Geneva Protocol I, above n 15, art 52 provides that in so far as objects are concerned, military objectives are limited to those objects which by their nature, location, purpose or use make an effective contribution to military action and whose partial or total destruction, capture or neutralization, in the circumstances ruling at the time, offers a definite military advantage. See also ICRC Customary International Humanitarian Law Study, above n 19 , rule 8 . 
(b) the prohibition on carrying out attacks which are reckless as to the distinction between military objectives on the one hand, and civilians, the civilian population, civilian objects and other specially protected persons and objects on the other - that is, "indiscriminate attacks"; 62

(c) the prohibition on carrying out attacks upon military objectives which, although they are themselves lawfully available targets, can be nevertheless expected to result in loss of life or injury to civilians or damage to civilian objects or other protected person or objects which is out of proportion to the concrete and direct military advantage anticipated, that is, "disproportionate attacks". ${ }^{63}$

The evidence clearly demonstrated that General Galić breached all three prohibitions. ${ }^{64}$ However, Galić was not convicted of any of these war crimes, ${ }^{65}$ but rather for murder as a crime

62 Geneva Protocol I, above n 15, art 51(4) provides that indiscriminate attacks are: (a) those which are not directed at a specific military objective; (b) those which employ a method or means of combat which cannot be directed at a specific military objective; or, (c) those which employ a method or means of combat the effects of which cannot be limited as required by Protocol I; and consequently, in each such case, are of a nature to strike military objectives and civilians or civilian objects without distinction; art 51(5)(a) provides that among others, the following types of attacks are to be considered as indiscriminate: (a) an attack by bombardment by any methods or means which treat as a single military objective a number of clearly separated and distinct military objectives located in a city, town, village or other area containing a similar concentration of civilians or civilian objects. See also ICRC Customary International Humanitarian Law Study, above n 19, rule 12. In order to accommodate the fact that the ICTY Statute does not actually mention indiscriminate attacks, the Trial Chamber in the Galic case, as in previous trials, found that "indiscriminate attacks may qualify as direct attacks against civilians" and that the prohibition reflects a well established rule of customary international law: see Galić Trial, above n 5, at [57].

63 Geneva Protocol I, above n 15, art 57(2)(a)(iii) provides that those who plan or decide upon an attack shall refrain from deciding to launch any attack which may be expected to cause incidental loss of civilian life, injury to civilians, damage to civilian objects or a combination thereof, which would be excessive in relation to the concrete and direct military advantage gained; art 51(5)(b) provides that disproportionate attacks are an example of indiscriminate attacks, however, the two type of attack are almost invariably treated as being distinct, though related, subjects; art 85(3)(b) provides that when committed wilfully, and causing death or serious injury to body or health, launching an indiscriminate attack affecting the civilian population or civilian objects in the knowledge that such attack will cause excessive loss of life, injury to civilians or damage to civilian objects, as defined in art 57(2)(a)(iii), is a grave breach of Protocol I. Rome Statute, above $\mathrm{n} 16$, art 8(b)(iv) provides that intentionally launching an attack in the knowledge that such attack will cause incidental loss of life or injury to civilians or damage to civilian objects which would be clearly excessive in relation to the concrete and direct overall military advantage anticipated is a war crime. See also ICRC Customary International Humanitarian Law Study, above n 19, rule 14. The Trial Chamber found that a disproportionate attack means that the attack was launched wilfully and in the knowledge of circumstances giving rise to the expectations of excessive civilian casualties: see Galic Trial, above n 5, at [59].

64 See Galić Trial, above n 5, at [58] (footnotes omitted):

The practical application of the principle of distinction requires that those who plan or launch an attack take all feasible precautions to verify that the objectives attacked are neither civilians nor civilian 
against humanity through shelling. Both the Galić case and subsequently the Strugar case ${ }^{66}$ established that killing a civilian by the use of artillery still constitutes murder in terms of the jurisdiction of the ICTY. Neither the remoteness of the target nor the seemingly impersonal nature of bombardment alters that fact.

When confronted about the shelling activities, the BSA would argue that the deaths incurred were simply collateral casualties from attacks on legitimate targets, and that the use of artillery was essentially no more than retaliation for attacks from the Presidency Forces. One of the features of the BSA shelling campaign was indeed the use of massive firepower in reply to any Presidency Forces' fire or attacks. As Cutler puts it: ${ }^{67}$

The Serbs consistently claimed to me that they would only fire in response to fire from the Bosnian

Forces in Sarajevo. I saw many examples of this when the Bosnians would fire a few mortar shells out from the city. This was in turn responded to ten-fold with incoming fire from the Serbs on to any part of the city.

It is sometimes asserted, particularly in the media, that to attack an opposing force with overwhelming strength is a breach of the rule against disproportionate attack. There is no such application of the rule under the LOAC. The law does not require a force to forego the advantage it may have by virtue of being militarily stronger, better armed, or better placed strategically or tactically.

The use of massive and destructive firepower against an opposing force, particularly one that is relatively unsophisticated or ill-armed, may affect the palatability or justifiability of a particular use of force from a moral, political or public relations point of view. The proportionality equation in the LOAC, however, relates solely to the incidental loss of life or injury to civilians or other specially

objects, so as to spare civilians as much as possible. Once the military character of a target has been ascertained, commanders must consider whether striking this target is "expected to cause incidental loss of life, injury to civilians, damage to civilian objectives or a combination thereof, which would be excessive in relation to the concrete and direct military advantage anticipated". If such casualties are expected to result, the attack should not be pursued. The basic obligation to spare civilians and civilian objects as much as possible must guide the attacking party when considering the proportionality of an attack. In determining whether an attack was proportionate it is necessary to examine whether a reasonably well-informed person in the circumstances of the actual perpetrator, making reasonable use of the information available to him or her, could have expected excessive civilian casualties to result from the attack.

65 The cumulative nature of the charges and the reason for dismissing those that were subsumed within the greater or more specific offences are set out in Galić Trial, above n 5, at [750]-[752].

66 Prosecutor v Pavle Strugar (Judgment) (31 January 2005) IT-01-42-T (Trial Chamber, ICTY). Strugar was a Montenegrin officer of the Yugoslav Army responsible for the siege of Dubrovnik in 1991.

67 Lieutenant Colonel Cutler Witness Statement to ICTY (13 January 1997) [Cutler Witness Statement]. 
protected persons, and incidental damage to civilian and other protected objects caused by an attack - not the number of enemy combatants killed.

If the BSA forces had directed their ten-fold retaliations solely at combatants of the Presidency Forces or military objectives, therefore, it is doubtful that they could have been faulted legally. That, however, is not what they did. As Cutler observes, the fire was directed at "any part of the city". He continues: "[t]hese shells were not necessarily directed at the area of confrontation (that is, the front line), but would often be targeted on civilian targets such as water lines, bread queues and residential areas". ${ }^{68}$ As Fenrick observed: ${ }^{69}$

Some of the shelling into the populated quarters of the city may well have a bona fide military objective

such as counter battery fire on elusive [Bosnia-Herzegovina's] artillery. However the sheer weight of fire

precludes any discussion of proportionality.

The fact that Presidency Forces not infrequently fired mortars from positions close to protected buildings, such as hospitals, complicates matters, since these actions were undoubtedly in breach of the LOAC, too. ${ }^{70}$ However, BSA responses could not be termed reprisals since they were directed against civilians and other protected persons, ${ }^{71}$ and the actions of the Presidency Forces, even if unlawful, could not legally convert the entire city into a free fire zone. ${ }^{72}$

\section{TERROR ATTACKS}

The use of terror as a weapon against the inhabitants of a defended place is scarcely new. The inhabitants of many towns which could have held out for substantial periods surrendered early in

68 Ibid.

69 Fenrick Report, above n 27, at 23.

70 See Geneva Protocol I, above n 15, art 13(4). There is evidence that the defenders in Sarajevo frequently fired mortars from the grounds of Kosevo Hospital in violation of this principle: see Cutler Witness Statement, above n 67, at 5. See Separate and Partially Dissenting Opinion of Judge Nieto-Navia, above n 6 , at [11]. There is also some evidence that Presidency Forces may have fired upon their own civilian population for propaganda effect on occasions.

71 A "reprisal" is an action taken by a party to a conflict, which would otherwise be unlawful, for the purpose of forcing an opposing party to the conflict to comply with the LOAC. It is prohibited to conduct reprisals against the persons and objects protected by the LOAC. In particular, it is prohibited to take reprisal against prisoners of war, retained personnel, detainees and internees; persons who are hors de combat through being sick, wounded or shipwrecked; hospitals and medical units; civilians and civilian objects and cultural property and places of worship. See, in particular, Geneva Protocol I, above n 15, art 51(6).

72 The defence of tu quoque (you also) is not available in respect of allegations of breaches of the LOAC or other crimes at international law. The Trial Chamber in Prosecutor v Zoran Kupreškić et al (Judgment) (14 June 2000) ICTY IT-95-16 (Trial Chamber, ICTY) at [515]-[520] found that the $t u$ quoque principle is fallacious and inapplicable and that the bulk of the obligations under the LOAC are unconditional and not based on reciprocity. 
order to avoid the various ghastly fates promised them by the attackers if they did not. From medieval times a distinction was drawn between town and fortified position that surrendered, and those that held out until taken by assault. As Keen observes, very different rules obtained for a town that declined to surrender by appointment or treaty: ${ }^{73}$

In a city taken by storm almost any licence was condoned by law. Only churches and churchmen were technically secure. But even they were not often spared. Women could be raped, and men killed out of hand. All the goods of the inhabitants were regarded as forfeit.

The prospect of rape and pillage was regarded as an incentive for the besieging troops to continue in their arduous and dangerous tasks, but equally the well-advertised prospect of the town being sacked amidst great barbarity if it did not speedily surrender served its own tactical purposes too.

A variation of this theme is the notion that the use of terror will "break the will of the enemy to fight" or will cause the civilian population to lose confidence in a government that cannot protect them, a theory which also found expression in World War II bombing campaigns. ${ }^{74}$ Lastly, terror may be seen as an end in itself, particularly when motivated by racial or religious hatred. This seems to have been a strong motive in the case of Sarajevo. ${ }^{75}$

The prohibition against terror attacks is really an amplification of the absolute prohibition on attacking civilians and the prohibition on indiscriminate attacks. As with indiscriminate attacks, terror attacks may sometimes include isolated elements that could possibly be justified as an attack on a legitimate military objective. If the predominant aim of an attack, however, is to cause terror amongst the civilian population, the attack is unlawful and the fact that it might also strike some legitimate targets does not provide an excuse. ${ }^{76}$

73 Maurice Keen The Laws of War in the Late Middle Ages (Routledge and Kegan Paul, London, 1965) at 123.

74 See generally W Hays Parks "'Precision' and 'Area' Bombing: Who Did Which, and When?" (1995) 18 J Strategic Stud 145.

75 The Trial Chamber found that "the attacks on civilians were numerous, but were not consistently so intense as to suggest an attempt by the Sarajevo Romanija Corps to wipe out or even deplete the civilian population through attrition", that those attacks "had no discernible significance in military terms ..., but very clearly [carried] the message that no Sarajevo civilian was safe anywhere, at any time of day or night", and that "the only reasonable conclusion in light of the evidence in the Trial Record is that the primary purpose of the campaign was to instil in the civilian population a state of extreme fear": Galić Trial, above n 5, at [593]. The Appeals Chamber upheld this finding: Galić Appeal, above n 5, at [107].

76 The Trial Chamber found that the crime of terror against the civilian population is constituted of:

1. Acts of violence directed against the civilian population or individual civilians not taking direct part in hostilities causing death or serious injury to body or health within the civilian population. 2 . The offender wilfully made the civilian population or individual civilians not taking direct part in hostilities the object of those acts of violence. 3 . The above offence was committed with the primary purpose of spreading terror among the civilian population. 
It is an unfortunate fact that almost all methods of warfare are likely to cause great fear to civilians who are in the vicinity of combat action. However, the prohibition is directed at actions that are calculated at generating such fear, such as the placement of improvised explosive devices in places where civilians are expected to gather, and indiscriminate shelling or sniping. ${ }^{77}$

The Sarajevo Romanija Corps under Galić's command directed shelling and sniping at civilians who were: ${ }^{78}$

... tending vegetable plots, queuing for bread, collecting water, attending funerals, shopping in markets,

riding on trams, gathering wood, or simply walking with their children or friends. People were even

injured and killed inside their own homes, being hit by bullets and shrapnel that came through the

windows.

The issue of shelling has been dealt with in some depth above, but the use of snipers demands further consideration. As with shelling, the use of snipers is permitted under the LOAC. Snipers are frequently employed to target commanders and other high-value individuals in the opposing force. ${ }^{79}$ Equally, they may be used to target individual combatants of much lower prestige with the intent of causing surprise, uncertainty and fear. ${ }^{80}$ The psychological effect of sniping is often disproportionate to the actual casualties imposed, and it can be seen that, particularly in irregular warfare, the use of the sniper and the deliberate infliction of fear go hand-in-hand. Combatants, however, are not protected by the law from even the worst terror that the enemy can inflict upon them. Civilians and other protected persons, on the other hand, are.

Whatever they may legitimately do to bring death and disarray amongst combatants, snipers cannot lawfully target civilians and most particularly cannot be used to inflict terror on the civilian population. ${ }^{81}$ Because of their training and the weapons used ${ }^{82}$ there can be little doubt that the

The majority of the Chamber rejected both the Prosecution's and the Defence's submissions that actual infliction of terror is an element of the crime of terror: Galić Trial, above n 5, at [133]-[134]. The Appeals Chamber upheld this finding: Galić Appeal, above n 5, at [104].

77 See Galić Appeal, above n 5, at [105]-[109] which deal with the appellant's submission that the prohibition "excludes terror which is not intended by a belligerent".

78 Galić Indictment, above n 10

79 Sniping is described and defined in the Galić Trial, above n 5, at [182]-[184].

80 See for example Department of the Army "Combined Arms Operations in Urban Terrain" (28 February 2002) US Army Field Manual FM 3-06.11 at ch 6-4.

81 The Prosecution submitted that the purpose behind the campaign of targeting civilians, which was built on the territorial, topographical, weaponry and munitions advantages enjoyed by the Sarajevo Romanija Corps over its opponent, was a crude application of pressure on the Bosnia-Herzegovina government. It explains that the purpose of the campaign was to undermine the government's popular support from within the city to maintain the conflict, and to undermine the morale of the Bosnia-Herzegovina's combatants, by reminding 
shooters knew the civilian nature of their targets. ${ }^{83}$ If bombardment has the illusion of being impersonal, sniping clearly is not. Axiomatically, the sniper must see and identify the man, woman or child who is to be shot. Similarly, if shelling can be dismissed as inaccurate (however dubiously), sniping cannot. Such persistent and monotonous execution of civilians and other protected persons can only be achieved by someone with the conviction that the victims are "not real people". 84

From one perspective, the "Sarajevo jurisprudence" produced no surprising or novel rules about the use of snipers in siege, or any other form of warfare. The cases merely reaffirmed the fact that members of armed forces employed as snipers are bound by all rules of the LOAC just as are all other combatants. Stanislav Galić was, however, the first person to be held guilty by the ICTY of spreading terror among the civilian population through the use of sniping and this very novelty caused him to assert that that the ICTY had no jurisdiction as "there exists no international crime of terror" 85 and the charge, therefore, violated the principle of nullum crimen sine lege. The majority in the Trial Chamber found that it had jurisdiction over attacks carried out against civilians, as set out in Article 3 of the ICTY Statute and that attacks intended to cause terror fell within this jurisdiction. ${ }^{86}$ The Appeal Chamber upheld the finding that this crime was deeply rooted in customary international law and that it also found its expression in treaty law, including the prohibitions set forth in Article 51(2) of Additional Protocol I, namely that "[a]cts or threats of

them that so long as they fought, their families behind them were in more danger than themselves: Galic Trial, above n 5, at [576].

82 Galić's defence team attempted to deny that the activity actually qualified as sniping, since he claimed it was conducted with ordinary assault rifles - not specialised rifles with telescopic scopes. This was rejected by the ICTY Trial Chamber: Galić Trial, above n 5, at [182]-[184]. In the subsequent Dragomir Milosević trial, a great deal more attention was paid to the techniques and equipment used in the sniping campaign, including evidence from expert snipers from North Atlantic Treaty Organization forces: Milosević Trial, above $n$, at [38].

83 At least one of the snipers was an Olympic shooting team contender, as was one of the defenders. The story of Vlado Sarzinsky and Slavko Simić was later to be dramatised in the television movie "Shot Through the Heart". Anti-aircraft weapons too were used in a lethally accurate direct-fire anti-personnel role, with horrific effects.

84 A comment made by General Mladić to Lieutenant Colonel Cutler on Serbian Christmas Day 1993: see Cutler Witness Statement, above n 67, at 5.

85 Defence Notice of Appeal, at [25]. Galić also stated that "there is no such ... criminal offence in the customary law", "this alleged offence was never criminalized", and "such an alleged offence could not be based on treaty law": see Galić Appeal, above n 5, at footnote 239.

86 In his dissenting opinion, Judge Nieto-Navia contested among other things that the prohibition of spreading terror among the civilian population could be found in treaty law: see Separate and Partially Dissenting Opinion of Judge Nieto-Navia, above n 6, at [108]. 
violence the primary purpose of which is to spread terror among the civilian population are prohibited". 87

Galić also unsuccessfully argued that the Prosecution had not proved that the acts of sniping were carried out with the primary purpose of spreading terror among the civilian population. However, the lesson that emerges from the ICTY's close judicial examination of the tactics of sniping is that the use of snipers by modern commanders, lawful in itself, must be tightly controlled if it is not to descend into a veritable reign of terror, for which the commander may face criminal responsibility.

\section{STARVATION}

"Starvation tactics" are those activities which are intended to deprive the adversary of the essentials of life, such as food, water or medical supplies. ${ }^{88}$ In addition to food and water, it can also mean vital utilities and commodities such as fuel in winter, electricity and sewerage systems. Such tactics are not unlawful when applied to the interdiction of logistic support for enemy forces, or the disruption of utilities such as power supplies that are being used as part of the opposing force's command, control, communications or intelligence system. There is no rule prohibiting the starvation of enemy combatants (unless they become hors de combat through wounds, sickness, shipwreck or capture). Such tactics are, however, unlawful when directed against the civilian population. In a siege situation, matters are complicated by the fact that both combatants and civilians are highly likely to rely on exactly the same supplies and utilities. ${ }^{89}$ For example, destruction of a power supply that may be highly disruptive to a command and communication system of the opposing force will also prove fatal to a baby in an incubator.

The Special Rapporteur of the United Nations Commission on Human Rights observed: ${ }^{90}$

Sarajevo has been the scene of some of the gravest violations of human rights in the course of this conflict. ... The humanitarian situation has also been extremely serious, with acute food shortages and problems with utilities which have frequently been used as a weapon of war.

87 The Appeals Chamber was "satisfied that the prohibition of terror against the civilian population as enshrined in Article 51(2) of Additional Protocol I and Article 13(2) of Additional Protocol II, was a part of customary international law from the time of its inclusion in those treaties": Galic Appeal, above n 5, at [86].

88 For a comprehensive view of legality of the use of starvation before the coming into force of Geneva Protocols I and II, see GA Mudge "Starvation as a Means of Warfare" (1969-1970) 4 Int'l L 228.

89 See Y Dinstein "Siege, Warfare and the Starvation of Civilians" in AJM Delissen and GJ Tanja (eds) Humanitarian Law of Armed Conflict: Challenges Ahead. Essays in Honour of Frits Kalshoven (Martinus Nijhoff Publishers, Dordrecht, 1991) 145 at 148-152.

90 Situation of Human Rights in the Former Yugoslavia GA Res 50/727 annex at [54], A/Res/50/727 (1995). 
BSA forces frequently interrupted and pillaged ${ }^{91}$ the supply of aid and failed to restore electricity or water utilities when they broke down. As if this strangle-hold on supplies was not bad enough, BSA shelling and sniping frequently concentrated on food queues and water points. Although most likely intended to simply kill civilians outright, this shelling and sniping had the collateral effect of causing people to move around as little as possible. In the words of one observer, some old people were "literally dying of malnutrition because they were too terrified to come out". 92

Depriving the inhabitants of the necessities of life is perhaps one of the most consistently applied, and most effective, techniques of siege warfare. The Prosecutor alleged the situation in Sarajevo was one which reduced the inhabitants to a "state of medieval deprivation in which they were in constant fear of death". ${ }^{93}$ It is poignant that the Middle Ages is used as a reference point since it is from this period that much of what we know of the laws and customs of war relating to sieges springs. Denying food and water to the besieged was certainly a feature of such warfare through the whole of this period and remained so well into the modern era.

Lest we conclude that the practice was universal, however, we should perhaps note that the idea of starving out the inhabitants of a pā, although practised from time to time, was largely antithetical to Māori concepts of chivalry. "Colonel" Hamilton-Browne colourfully contrasted Māori and European thought on this subject when he observed that: 94

$\ldots$ it had never been the custom of the chivalrous sportsmen-like savages [sic] to prevent the women

from leaving a besieged pah for the purpose of obtaining food and water. For ... how can a man's heart

be strong, and how can he fight well, should he be famished for want of sustenance?

Civilised white men, however, use hunger and thirst as two of their most formidable weapons, and did so even during the most chivalrous epochs ...

When Leningrad was besieged, both its defenders and the civilian population were on the point of starvation and it was thought likely that the civilian population would flee through German lines. Orders were issued to the German artillery to "prevent any such attempt at the greatest possible distance from our own lines by opening fire as early as possible, so that the infantry, if possible, is spared shooting on civilians". ${ }^{95}$ The law as it stood at that time was expressed as follows: ${ }^{96}$

91 See generally Marita Vihervuori "Starvation" in Gutman, Rieff and Anderson, above n 4, 344.

92 Evidence of Aston cited in Galić Trial, above n 5, at [222].

93 Galić Trial, above n 5, at [2].

94 Hamilton-Browne's "first-hand" accounts of the New Zealand Wars are devalued somewhat by the fact that he was not actually present at the events he describes and was not a colonel. He provides, nevertheless, an interesting commentary of his times. See Colonel G Hamilton-Browne With the Lost Legion in New Zealand (T Werner Laurie, Clifford's Inn, London, 1911).

95 High Command Case, above n 48, at 59. 
A belligerent commander may lawfully lay siege to a place controlled by the enemy and endeavour by a process of isolation to cause its surrender. The propriety of attempting to reduce it by starvation is not questioned. Hence the cutting off of every source of sustenance from without is deemed legitimate. It is said that if the commander of a besieged place expels the non-combatants, in order to lessen the number of those who consume his stock of provisions, it is lawful, though an extreme measure, to drive them back, so as to hasten the surrender.

The International Military Tribunal at Nuremberg found that "[w]e might wish the law were otherwise, but we must administer it as we find it. Consequently, we hold no criminality attaches on this charge". ${ }^{97}$ This sentiment, although in more cautious terms, is still to be found in the LOAC manuals of States that are not party to Geneva Protocol I. ${ }^{98}$

In 1977, Geneva Protocol I, however, introduced an absolute prohibition against starvation tactics being levied against civilians. ${ }^{99}$ A besieging force cannot, for example, destroy objects indispensable to the survival of the civilian population such as food-stuff, crops, livestock or drinking water. ${ }^{100}$

96 Charles Hyde International Law (2nd ed, Little, Brown and Company, Boston, 1945) vol 3 at 1802-1803. See also Instructions for the Government of Armies of the United States in the Field, General Orders No 100 (Lieber Code) (24 April 1863) reproduced in Schindler and Toman, above n 16, 3, art 17: "[w]ar is not carried on by arms alone. It is lawful to starve the hostile belligerent, armed or unarmed, so that it leads to the speedier subjection of the enemy"; art 18: "[w]hen a commander of a besieged place expels the noncombatants, in order to lessen the number of those who consume his stock of provisions, it is lawful, though an extreme measure, to drive them back, so as to hasten on the surrender".

97 High Command Case, above n 48, at 59.

98 See for example Department of the Army "The Law of Land Warfare" (18 July 1956) US Army Field Manual FM 27-10, at [44]. This manual is currently undergoing a comprehensive rewrite and this provision is likely to disappear.

99 Geneva Protocol I, above n 15, art 54 provides that starvation of civilians as a method of warfare is prohibited. See also Geneva Protocol II, above n 45, art 14 in respect of armed conflict not of an international character. Rome Statute, above n 16, art 8(2)(b)(xxv) now provides that using starvation of civilians as a method of warfare by depriving them of objects indispensable to their survival, including wilfully impeding relief supplies as provided for under the Geneva Conventions, is a war crime. Such tactics could also amount to a crime against humanity, as art 7(2)(b) provides that the crimes against humanity of "extermination" includes the intentional infliction of conditions of life, inter alia, the deprivation of access to food and medicine, calculated to bring about the destruction of part of a population. See also ICRC Customary International Humanitarian Law Study, above n 19, rule 54.

100 Geneva Protocol I, above n 15, art 54 protects food-stuffs, agricultural areas for the production of foodstuffs, crops, livestock, drinking water installations and supplies and irrigation works. These prohibitions do not apply to such objects used by an adverse party as sustenance solely for the members of its armed forces; or in direct support of military action. However, no actions against these objects may be taken which may be expected to leave the civilian population with such inadequate food or water as to cause its starvation or force its movement. Geneva Protocol II, above 45, art 14 provides that in armed conflict not of an international character starvation of the population is prohibited. 
There is, however, perhaps anachronistically, a provision retained in Geneva Protocol I by which a defender can derogate from the obligation so as to implement a "scorched earth" policy calculated to starve an invader who has not adequately provisioned his or her troops. ${ }^{101}$

Beyond these exceptions, however, the modern commander who wishes to comply with the LOAC is not only prohibited from deliberately starving the population of a besieged place, but is faced with the obligation to allow relief supplies through to the civilian inhabitants. When referring to the Leningrad example at his trial at Nuremberg, Reichsmarschall Herman Goering remarked caustically that he was "not aware of any other example in history in which the besieger generously supplies the besieged with food in order that they can resist longer". ${ }^{102}$ Yet, in 1949, Geneva Convention IV introduced the notion that commanders were indeed under an obligation to allow relief supplies into a city for the benefit of members of the civilian population, ${ }^{103}$ There is, however, a provision by which such relief can be temporarily suspended if there is reason to believe that it is being used, directly or indirectly, by the opposing force. ${ }^{104}$ But how useful is this? Does anyone imagine that a commander will allow combatants to starve while the civilian population eat? How would the ultimate use of food and other supplies be effectively monitored? It was an unfortunate fact that, due to the dangers to its staff, ${ }^{105}$ the International Committee of the Red Cross had left Sarajevo in May 1992 and could perform no such function. The report prepared for the Canadian War Crimes Investigative Team, after considering these legal and practical difficulties, concluded: ${ }^{106}$

$\ldots$ one is left with the unpalatable fact that, unless there is a neutral arbiter, the only way to starve out a

besieged military force, a legitimate act of war, is over the starved bodies of the civilian population.

A further complication is added by the fact that the prohibition against the deliberate starvation of the civilian population as a method of warfare is absolute, regardless of motive. If starvation of

101 Geneva Protocol I, above n 15, art 54(2). Derogation from these prohibitions may be made by a party to the conflict in the defence of its national territory against invasion within such territory under its own control where required by imperative military necessity. Reliance on "living off the land" is unlikely to form part of a modern battle plan.

102 Trial of the Major War Criminals (1947) 9 LRTWC at 349-350.

103 Geneva Convention IV, above n 20, art 23 provides that State parties shall allow the free passage of all consignments of medical and hospital stores and objects necessary for religious worship intended only for civilians of another high contracting party, even if the latter is its adversary.

104 There was some evidence that this very thing was occurring. See Separate and Partially Dissenting Opinion of Judge Nieto Navia, above n 6, at [7].

105 ICRC head of delegation Frédéric Maurice was ambushed in the city and died on 19 May 1992. The ICRC were out of Sarajevo for seven months as a result. See David Forsythe The Humanitarians (Cambridge University Press, Cambridge 2005) at 112.

106 Fenrick Report, above n 27, at 50. 
the civilian population cannot be used as a device to put pressure on the resources of a besieged force in the way that von Leeb had, neither can it be used to cause the civilian population to move out of the town. ${ }^{107}$ The besieging commander, in allowing a hungry population to leave, may by that very act be providing evidence of having used starvation to drive them away.

In the event, Galic was not charged with any offence relating to the use of starvation or the denial of the necessities of life of the civilian population. The reason for this may be quite simple: "as no one appears to have died of starvation, cold or dehydration in Sarajevo, it is unlikely anyone could be held liable for using starvation of civilians as a method of warfare during the siege". ${ }^{108}$

The massive United Nations-driven aid supply programme (along with the effect of the famous "Sarajevo Tunnel") managed to deliver food and other essentials to the people of Sarajevo in sufficient amounts to ensure that, although many people were in a state of frequent misery, it is difficult to prove that any known individual actually died. ${ }^{109}$ One can scarcely criticise the Prosecutor for not wanting to include a charge unless clear evidence of such deaths was available. Future prosecutions may not face this difficulty.

\section{THE DUTIES OF THE LAW-ABIDING BESIEGER}

So how would a commander who must lay siege to a place avoid the criminal responsibility incurred by General Galić? Obviously such a commander must not deliberately target civilians and civilian objects and cannot use terror as a weapon against civilians.

One must assume, however, that in a tightly-populated city such as Sarajevo, even a commander demonstrably more careful and humane than Galić is still going to cause a significant amount of incidental civilian casualties and property damage using artillery to respond to mortar attack from within. ${ }^{110}$ The combined effect of Articles 51 to 57 of Geneva Protocol I, with the added overlay of instruments such as The Hague Cultural Property Convention and its Protocols, ${ }^{111}$ is to severely

107 Geneva Protocol I, above n 15, art 54(2).

108 Fenrick Report, above n 27, at 50.

109 Judge Nieto-Nevia went further and concluded that the trial record "does not disclose that the population within the city suffered from widespread starvation or generalised shortage of medicine": Separate and Partially Dissenting Opinion of Judge Nieto-Navia, above n 6, at [8].

110 The Trial Chamber was seemingly without a great deal of sympathy for Galić on this front and did not regard this fact as an excuse: see Galić Trial, above n 5, at [765]. This subject is revisited by the Appeals Chamber: see Galić Appeal, above n 5, at [765].

111 Convention for the Protection of Cultural Property in the Event of Armed Conflict (opened for signature 14 May 1954, entered into force 7 August 1956) [Hague Cultural Property Convention]; Protocol for the Protection of Cultural Property in the Event of Armed Conflict (opened for signature 14 May 1954, entered into force 7 August 1956); Second Protocol to the Hague Convention of 1954 for the Protection of Cultural Property in the Event of Armed Conflict (opened for signature 26 March 1999, entered into force 9 March 2004) [Second Hague Cultural Property Protocol]. 
constrain the besieging commander's freedom to respond to such hit-and-run tactics. Seemingly, the only antidote to this tactic which meets with the LOAC requirement is to employ extraordinary care and precision in targeting, even if as a result, some military objectives escape an attack which the military situation would otherwise justify. The actions of the enemy do not provide an excuse for failures on this front.

A commander who plans or conducts a siege of a town or place is under an affirmative duty to take all feasible precautions in the choice of means ${ }^{112}$ and methods of attack to avoid, and in any event to minimise, incidental loss of life or injury to civilians and incidental damage to civilian objects. ${ }^{113}$ The commander must not launch an attack which he or she expects to cause incidental casualties and destruction that would be excessive in proportion to the anticipated military advantage. ${ }^{114}$ The Rome Statute of the International Criminal Court requires that to constitute a war crime the disproportionate effects of the attack must be "clearly excessive" in relation to the "overall" military advantage. The expression "clearly" will in most cases add little to the commander's understanding of his or her duty since the rule is entirely based on good faith assessments of likely outcomes. The expression indicates, however, that to be a war crime the disproportion of civilian casualties to military advantage must amount to more than a simple miscalculation. ${ }^{115}$

112 A weapon is not rendered unlawful simply because it may, on occasions, cause damage beyond the limits of the military objective against which it is directed. Almost all weapons have this capacity. A weapon is only unlawful when its properties are such that its propensity to damage civilian objects and cause civilian casualties beyond the military objective is unable to be controlled. Indiscriminacy may also arise because the weapon in question is simply not accurate enough to be aimed discriminately. Obviously, the question of judging how accurate a weapon must be in order to comply with the LOAC is determined to a large degree by the state of available technology. Weapons that cannot be effectively aimed so as to avoid civilian casualties and damage, such as the multi-barrelled rocket launchers used by the BSA, are now generally regarded as indiscriminate if they are used in areas in which there are likely to be civilians and civilian objects as well as military objectives.

113 Geneva Protocol I, above n 15, art 57(2)(a)(ii) provides that those who plan or decide upon an attack shall take all feasible precautions in the choice of means and methods of attack with a view to avoiding or minimising incidental loss of civilian life, injury to civilians and damage to civilian objects. See also ICRC Customary International Humanitarian Law Study, above n 19, rules 15 and 17.

114 Above, n 62.

115 Rome Statute, above n 16, art 8 (b)(iv). The provision also introduces the expression "overall" as a qualifier to "military advantage anticipated". This inclusion is consistent with the terms of the New Zealand Declaration on Ratification of Protocol Additional to the Geneva Conventions of 12 August 1949 Relating to the Protection of Victims of International Armed Conflicts (Protocol I) (23 December 1987), which states that New Zealand understands that the military advantage anticipated from an attack is intended to refer to the attack as a whole and not from isolated or particular parts of that attack and the term "military advantage" involves a number of considerations, including the security of attacking forces. "Concrete and direct military advantage anticipated" means a bona fide expectation that the attack will make a relevant and proportional contribution to the objective of the military attack involved. It also provides that intentionally 
The commander must do everything in his or her power to warn the authorities of the besieged place of attacks which may affect the civilian population, and in particular before commencing a bombardment or shelling, except where the operational requirements prevent the giving of such warning. ${ }^{116}$

All specifically protected persons and objects must be respected and protected just as they must in an open battle-space. However, the commander of a besieging force faces further difficulty in that almost all of these protected persons and objects will be found within the town and often within close proximity of each other and the defending forces. Obviously, hospitals and other medical units must be respected and protected. ${ }^{117}$ So too must civil defence personnel and property, who will almost certainly be operating in any urban environment under attack. ${ }^{118}$ Lastly, United Nations personnel and property and associated personnel, a very likely presence in any city under siege, are subject to special protection. ${ }^{119}$

launching an attack in the knowledge that such attack will cause incidental loss of life or injury to civilians or damage to civilian objects which would be clearly excessive in relation to the concrete and direct overall military advantage anticipated is a war crime. The second part of the New Zealand Declaration was cited with approval by the Trial Chamber in Galić Trial, above n 5, at [58] and [106].

116 Geneva Protocol I, above n 15, art 57(2)(c) provides that effective advance warning shall be given of attacks which may affect the civilian population, unless circumstances do not permit. ICRC Customary International Humanitarian Law Study, above n 19, rule 20 states that each party to the conflict must give effective advance warning of attacks which may affect the civilian population, unless circumstances do not permit. See also Hague Regulations 1907, above n 17, art 26.

117 Hague Regulations 1907, above n 16, art 27 provides that in sieges and bombardments all necessary steps must be taken to spare as far as possible all hospitals and places where the sick or wounded are collected, provided that they are not used at the same time for military purposes. See also Hague Convention IX, above n 16, art 5 in the case of bombardment by naval forces. Geneva Convention IV, above n 20, art 18 provides that civilian hospitals may not be the subject of attack. Geneva Protocol I, above n 15, art 8(e) defines medical units to include military and civilian hospitals and other medical facilities; art 12(1) provides that such units shall not be the subject of attack.

118 Geneva Protocol I, above n 15, ch VI. There is evidence that BSA guns deliberately targeted fire-fighters who responded to fires caused by the shelling: see Galic Trial, above n 5, at [218].

119 UNSMO vehicles and personnel were shot at on a number of occasions in Sarajevo: see Cutler Witness Statement, above n 67, at 7. See Convention on the Safety of United Nations and Associated Personnel (opened for signature 9 December 1994, entered into force 15 January 1999) and Optional Protocol to Convention on the Safety of United Nations and Associated Personnel (opened for signature 8 December 2005, not yet entered into force). Rome Statute, above n 16, art 8(2)(b)(iii) provides that attacking the personnel, installations, material, units or vehicles involved in a United Nations humanitarian assistance or peacekeeping mission, as long as they are entitled to the protection given to civilians or civilian objects under the LOAC, is a war crime; art 8(2)(e)(iii) provides that such an attack in an armed conflict not of an international character is a war crime. See generally L Maybee "Attacks on United Nations Peacekeepers: Can International Law Protect the Blue Helmets?" (2002) NZAF Law Rev 25. 
The besieging commander must do everything feasible to verify the legitimacy of objectives he or she wishes to attack ${ }^{120}$ and may need to cancel or suspend any assault if it becomes apparent that the objective is not a military one, is subject to special protection, or the attack may be expected to cause excessive incidental loss of civilian life. ${ }^{121}$ The commander may in fact need to choose targets likely to cause the least incidental loss of life or injury to civilians or incidental damage to civilian objects when such a choice is available. ${ }^{122}$

The commander of a besieging force will likely need to take even greater care to avoid needlessly damaging cultural property, ${ }^{123}$ places of worship, ${ }^{124}$ educational ${ }^{125}$ and charitable

120 Geneva Protocol I, above n 15, art 57(2)(a)(i) provides that those who plan or decide upon an attack shall do everything feasible to verify that the objectives to be attacked are neither civilian nor civilian objects and are not subject to special protection, but are military objectives within the meaning of art 52(2) and that it is not prohibited to attack them.

121 Geneva Protocol I, above n 15, art 57(2)(b) provides that an attack shall be cancelled or suspended if it becomes apparent that the objective is not a military one or that the attack may be expected to cause incidental loss of civilian life, injury to civilians, damage to civilian objects, or a combination thereof, which would be excessive in relation to the concrete and direct military advantage anticipated. See also ICRC Customary International Humanitarian Law Study, above n 19, rule 19.

122 Geneva Protocol I, above n 15, art 57(3) provides that when a choice is possible between several military objectives for obtaining a similar military advantage, the objective to be selected shall be that the attack may be expected to ensure the least damage to civilian lives and civilian objects. ICRC Customary International Humanitarian Law Study, above n 19, rule 21 states that when a choice is possible between several military objectives for obtaining a similar military advantage, the objective to be selected must be that the attack may be expected to cause the least danger to civilian lives and to civilian objects.

123 Hague Cultural Property Convention, above n 111, art 4(1) provides that it is prohibited to commit any act of hostility directed against cultural property. Geneva Protocol I, above n 15, art 53(a) provides that it is prohibited to commit any acts of hostility directed against historic monuments, works of art, or places of worship which constitute the cultural or spiritual heritage of peoples; art 85 provides that making the clearly recognised historic monuments, works of art or places of worship which constitute the cultural or spiritual heritage of peoples and to which special protection has been given by special arrangement, for example, within the framework of a competent international organisation, the object of attack, where there is no evidence of misuse by the opposing force and the property in question is not located in the immediate proximity of military objectives, is a grave breach. See also Geneva Protocol II, above n 45, art 16 which prohibits any act of hostility against such cultural property or places of worship in the course of an armed conflict not of an international character. ICRC Customary International Humanitarian Law Study, above n 19 , rule $38 \mathrm{~B}$ states that property of great importance to the cultural heritage of every people must not be the object of attack unless imperatively required by military necessity.

124 Hague Regulations 1907, above n 16, art 27 provides that in sieges and bombardments all necessary steps must be taken to spare, as far as possible, buildings dedicated to religion, provided that they are not used at the same time for military purposes. See also Hague Convention IX, above n 16, art 5 in respect of bombardment by naval forces. Geneva Protocol I, above n 15, art 52(3) provides that in cases of doubt as to whether an object which is normally dedicated to civilian purposes such as a place of worship is being used to make an effective contribution to military action, it shall be presumed not to be so used. Rome Statute, above $\mathrm{n} 16$, art $8(2)(\mathrm{b})(\mathrm{x})$ provides that intentionally directing an attack against buildings dedicated to 
institutions ${ }^{126}$ than the commander in an open battle. ${ }^{127}$ The obligation of restraint on the part of the besieging commander becomes greater still when the town contains cultural property of greatest importance for humanity which is entitled to enhanced protection. ${ }^{128}$ The probability of such objects being within the battle-space markedly increases in cases where warfare extends to the "old towns" of the world. ${ }^{129}$

Although public utilities (such as electric power grids) may be attacked to deny power to enemy military forces and installations, for example, command, control and communication systems, commanders authorising such attacks need to determine the anticipated effect of those attacks to ensure that they do not leave the civilian population with inadequate water or heating supplies. Unless there are serious reasons to believe that they will be misused, the commander must allow the

religion, unless they are a military objective, is a war crime. See also art 8(2)(e)(iv) in respect of an armed conflict not of an international character.

125 Geneva Protocol I, above n 15, art 52(3) provides that a school is an example of a building which should be presumed not to be a military objective. Rome Statute, above n 16, art 8(2)(b)(ix) provides that intentionally directing an attack against buildings dedicated to education, provided they are not military objectives, is a war crime. See also art 8(2)(e)(iv) in respect of a conflict not of an international character.

126 Hague Regulations 1907, above n 16. See also Hague Convention IX, above n 16, art 5 in respect of bombardment by naval forces. See also Draft Rules of Aerial Warfare, above n 16, art 25. Rome Statute, above $\mathrm{n} \mathrm{16}$, art $8(2)(\mathrm{b})(\mathrm{ix})$ provides that intentionally directing an attack against buildings used for charitable purposes, provided they are not military objectives, is a war crime; art $8(2)(\mathrm{e})(\mathrm{iv})$ states that intentionally directing an attack against buildings used for charitable purposes, provided they are not military objectives, in the course of a conflict not of an international character, is a war crime.

127 The obligations are not absolute and do not preclude a commander from attacking such objects when military necessity so demands. Hague Cultural Property Convention, above n 111, art 4(2) provides that the obligations to respect cultural property may only be waived where military necessity imperatively requires; art 11 provides that use of specially protected cultural property or its surroundings for military purposes releases the opposing party from its obligations to ensure the immunity of the property.

128 Second Hague Cultural Property Protocol, above n 111, art 12 provides that the parties to a conflict shall ensure the immunity of cultural property under enhanced protection by refraining from making such property the object of attack; art 13 provides for even greater precaution before an attack can be executed, even if such objects have become military objectives.

129 On 18 May 1992 (preceding Galić's assumption of command), white phosphorous incendiary shells were deliberately used to destroy the irreplaceable collection of manuscripts in the Oriental Institute of Sarajevo. 15,000 volumes and over 2,000 rare documents were destroyed. Although Galić's shelling campaign undoubtedly did damage to buildings of cultural importance in Sarajevo, this fact did not greatly compound the other grounds of criminality for which he faced trial. See, however, Prosecutor v Pavle Strugar (Judgment), above n 66: Strugar was sentenced to eight years' imprisonment for his involvement in the military campaign against the Dubrovnik region in 1991, including destruction or wilful damage of the UNESCO protected town of Dubrovnik. 
free passage of all consignments of humanitarian aid ${ }^{130}$ and other essentials to reach the civilian population. $^{131}$

There are obligations too on the defending side. ${ }^{132}$ Amongst other things, the authorities of a besieged town must indicate the presence of buildings dedicated to religion, art, science or charitable purposes, historic monuments, hospitals and places where the sick and wounded are collected, by distinctive and visible signs which are notified to the attacking force ${ }^{133}$ and must not endanger such objects by using them as part of their defensive operations. They must also endeavour to conclude local agreements for the removal from the besieged town or place of the wounded, sick, infirm and aged persons, children and maternity cases, and for the passage of ministers of all religions, medical personnel and medical equipment on their way to such areas. ${ }^{134}$ However, as noted above, the failure of a defender to meet these obligations does not provide the besieger with a carte blanche to ignore the LOAC.

\section{CONCLUSION}

There is not much evidence to suggest that General Galić ever intended to comply with the ${ }_{\text {LOAC }}{ }^{135}$ and the gross excesses of his shelling, sniping and terror strategy made the illegality of his

130 Geneva Convention IV, above n 20, art 23. See Part X Starvation above.

131 Ibid.

132 See Geneva Protocol I, above n 15, art 58 for precautions against the effects of attack.

133 Hague Regulations 1907, above n 16, art 27 provides that it is the duty of the besieged to indicate the presence of distinctive and visible signs dedicated to religion, art, science or charitable purposes, historic monuments, hospitals, and places where the sick and wounded are collected, which shall be notified to the enemy beforehand. See also Hague Cultural Property Convention, above n 111, art 4(1) which prohibits any use of the cultural property and its immediate surroundings or of the appliances in use for its protection for any purposes which are likely to expose it to destruction or damage in the event of armed conflict. Geneva Protocol I, above n 15, art 53(b) provides that it is prohibited to use cultural property and places of worship in support of the military effort. Geneva Protocol II, above n 45, art 16 prohibits the use of cultural property or places of worship in support of the military effort the course of an armed conflict not of an international character.

134 Geneva Convention IV, above n 20, art 18 provides that the parties to the conflict shall endeavour to conclude local agreements for the removal, from besieged or encircled areas, of wounded, sick, infirm, and aged persons, children and maternity cases, and for the passage of ministers of all religions, medical personnel and medical equipment on their way to such areas.

135 The parties to the conflict committed themselves to comply with the laws governing the conduct of hostilities and had signed an agreement to that effect on 22 May 1992. Instructively on appeal, Galić argued that the 22 May 1992 Agreement was not binding on the parties and even if binding did not give rise to individual criminal responsibility on the part of the parties: Galić Appeal, above n 5, at [86]. The Appeals Chamber also noted that the Trial Chamber did consider the evidence indicating that Galić conveyed instructions to respect the 1949 Geneva Conventions. However, those instructions instilled an inadequate and erroneous understanding of the obligations under the Conventions. For example, one battalion commander under Galić had the understanding that civilians had to be 300 metres away from a 
case (despite dissent on some points) relatively easy to determine. The result of the Galic trial does make clear, however, the difficulties presented by siege warfare for the commanders of attacking forces. Other commanders of the future may seek to take a more humane approach, yet will face many of the same difficulties.

Of the commander's "tool box" for dealing with an enemy ensconced in a built up area, assault and lawful trickery (ruses of war) are still available, although the former may be costly in lives and presents distinction and proportionality dilemmas all of its own. Bombardment and shelling, too, survive under the modern law - but only if they comply with the obligation of distinction. In addition to the fundamental obligation that such attack not be directed at civilians or civilian objects, it must not be indiscriminate, it must not cause disproportionate incidental casualties amongst civilians and other specifically protected persons and it must not cause disproportionate incidental damage to civilian and other specifically protected objects.

The use of terror attacks against civilians is completely prohibited, and unless there are no civilians present within the place under attack, the use of starvation of the opposing force is in practice severely curtailed - probably to the point where it can scarcely be considered as a viable option in operations where the commander seeks to comply with the LOAC.

With so few of the traditional techniques still available, is it possible for a commander to conduct a siege that is both lawful and effective? The answer is probably still, yes. But in doing so, he or she will be bound by a significant number of rules that may prove both frustrating and costly in lives and material.

This all paints a complicated picture of obligations for the modern commander which were not faced by the commanders of besieging forces of the past. However, we can be reasonably sure that armed forces will continue to prosecute sieges, and given the apparent difficulties besieging forces face, it will be little to wonder at if poorly armed or equipped forces turn to the urban environment as their battlefield of choice. This in turn may lead to greater casualties, not only for the besieging forces, but also for the civilian population of the town or city. Nevertheless, the Sarajevo example provides further proof, if any were needed, that the means and methods of warfare are not unlimited, and commanders of the future must exercise greater distinction, respect for civilian life and control of the military assets at their disposal than General Galic did, if they are to avoid the prospect of individual criminal responsibility.

confrontation line in order to escape targeting, which the Trial Chamber found to be obviously improper considering the context of an urban battlefield: Galić Appeal, above n 5, at [1158]. 